Marketing in Asia Group

\title{
Purchasing Decision Making of Cosmetics: A Comparative Study between Swiss and Chinese Consumers
}

\author{
Joana Sofia Neves Gomes \\ University of Applied Sciences \& Arts Northwestern, Switzerland \\ Swiss SME Research Center, China \\ Michael Jeive \\ University of Applied Sciences \& Arts Northwestern, Switzerland \\ Swiss SME Research Center, China
}

\section{Lynn L. K. Lim}

School of Business, University of Applied Sciences \& Arts Northwestern, Switzerland

\begin{abstract}
Despite the rapid growth of the Chinese market since the initial opening up in 1978, a significant number of international consumer goods companies have struggled to find a firm and consistently profitable foothold in the market. This is often attributed to national cultural differences. Using projective technique for data collection, the research analysed female cosmetic consumers in China and in Switzerland, a market that Western manufacturers are familiar with. Due to significant regional differences within both countries, the study analysed consumers from Shanghai and Harbin, and the French and German-speaking areas of Switzerland. The study found out that there are large differences between the behaviour of consumers in Switzerland and China, but also within each country, particularly China. However, there are some similarities between the behaviour of consumers from Switzerland and Harbin. The findings provide a good insight for marketers wanting to enter or change their strategy in China or Switzerland, but particularly for Western manufacturers who are already present and familiar with the Swiss market and want to succeed in the Chinese market.
\end{abstract}

Keywords: Consumer Behaviour, Purchasing Decision, Cosmetics, China, Switzerland 


\section{Introduction}

For the past three decades, China has experienced an extraordinary economic boom (Whyte, 2009, p.372), reaching second place in the World's largest economies ranking, only behind the United States (World Bank, 2016). Many Western brands have been attracted to invest in the Chinese market, making it one of the top Foreign Direct Investment destinations in the last years (United Nations, 2015).

However, after years of openness to foreign companies, even large brands are still failing to succeed in China (Marquis \& Yang, 2014) such as Garnier and Revlon (Roberts, 2014). The reason behind the failure of Western companies is often based on cultural aspects and misconceptions, which results in companies adopting the wrong approach to the market (Marquis \& Yang, 2014) and explains why further research on the Chinese market and culturally influenced behaviours is necessary.

Understanding Chinese consumer behaviours and attitudes could help marketers to design an effective mixed marketing strategy to gain repeated purchases customers, create brand loyalty, and expand domain in the Chinese market share (Nguyen, 2012). Therefore, the purpose of this research is to understand the differences between the purchasing behaviour of Chinese and Swiss buyers of cosmetics, going through the different steps of the purchasing process, providing a perspective for Western manufacturers of what needs to be taken into account when approaching the Chinese market. The Swiss market represents a country which Western manufacturers know well and are experienced in: large players from France, Germany and the U.S. have been present in the Swiss market for a long time (Euromonitor International, 2016; Cosmetics Business, 2012), helping to provide a basis for comparison.

The cosmetics market represents a strong market in both countries under analysis: China is the second largest market in the world (Reportlinker, 2015) and Switzerland has the second highest per-capita expenditure in cosmetics in Europe (Cosmetics Europe, 2016). Furthermore, this research gives an important contribution to limited literature on the purchasing behaviour of consumers of this industry and provides the first set of measurements for subsequent research in similar sectors, particularly between the two markets under analysis. Previous research on the behaviour of consumers of cosmetics in China never provided a comparison basis that is familiar to Western manufacturers. Regarding Switzerland, no previous studies on the behaviour of consumers of cosmetics are known.

Although the Chinese cosmetics industry has been object of a number of analyses (e.g. U.S. Commercial Service Hong Kong, 2015; Fung Business Intelligence Centre, 2013; HKTDC Research, 2015), there is still little research on new developments of this fast changing market (e.g. the emergence of new customer segments) (SSRCC, 2016). The research on the behaviour of cosmetics consumers in China is also limited, particularly when comparing it with the behaviour of customers from other countries. Therefore, the present research aims to identify the gap between the purchasing behaviour of Swiss and Chinese customers of cosmetics, providing useful data not 
only for practical applications within the cosmetics industry but also for the theoretical knowledge of the purchasing behaviour process in China and Switzerland. Switzerland and China are both very diverse countries. The French-speaking part of Switzerland is culturally more similar to France and gravitates more towards French brands and communications, whereas the German-speaking part is more similar to Germany and feels more comfortable with German and American brands (Javidan \& House, 2002; La Bua, 2011). In China, different city tiers differ in terms of income and consumer behaviour (Davies \& Raskovic, 2018). There is a significant difference in disposable income between urban and rural, the eastern coastline and the interior, and between tier 1 (more populated cities, such as Beijing and Shanghai), tier 2 cities (e.g. Xiamen and Harbin) and tier 3, 4 and 5 cities (smaller and less populated such as Fuzhou, Lanzhou or Anshan). In 2013, the percentage of the total sales of cosmetics in China in coastal areas was $60 \%$, in the middle areas was $24 \%$ and in the Western was $16 \%$ (Cosmoprof-Asia, 2013). However, due to the maturing of the market in tier 1 cities, cosmetics makers such as L'Oréal and Estée Lauder are increasing their brand presence in tier 2 and 3 cities. This can indicate that other brands are also going to strengthen their presence in these cities. Therefore, this research studies consumers from French-speaking and German-speaking Switzerland and from the Chinese cities of Shanghai (tier 1) and Harbin (tier 2).

\section{Literature Review}

\section{Consumer Behaviour}

The ability to predict consumer behaviour as a method of measuring abstract constructs is considered to be at the heart of marketing (Zaichkowsky, 2015), as it provides a better understanding not only of the subject of purchases but also of the purchasing motives and purchasing frequency (Schiffman \& Kanuk, 2007). It is the product of the interaction of many variables and several authors have developed models that explain this interaction (Engel, Kollat \& Blackwell, 1978; Hawkins \& Mothersbaugh, 2010). According to Hawkins and Mothersbaugh (2010), consumers' self-concept and lifestyle are influenced by external and internal factors. They result in needs and desires that are present in their daily life, many times resulting in a purchase. Their final decision, and the process to get to it, will then cause learnings that will affect many internal and external factors. 
Figure 1: The Nature of Consumer Behaviour - Business to Consumer Model

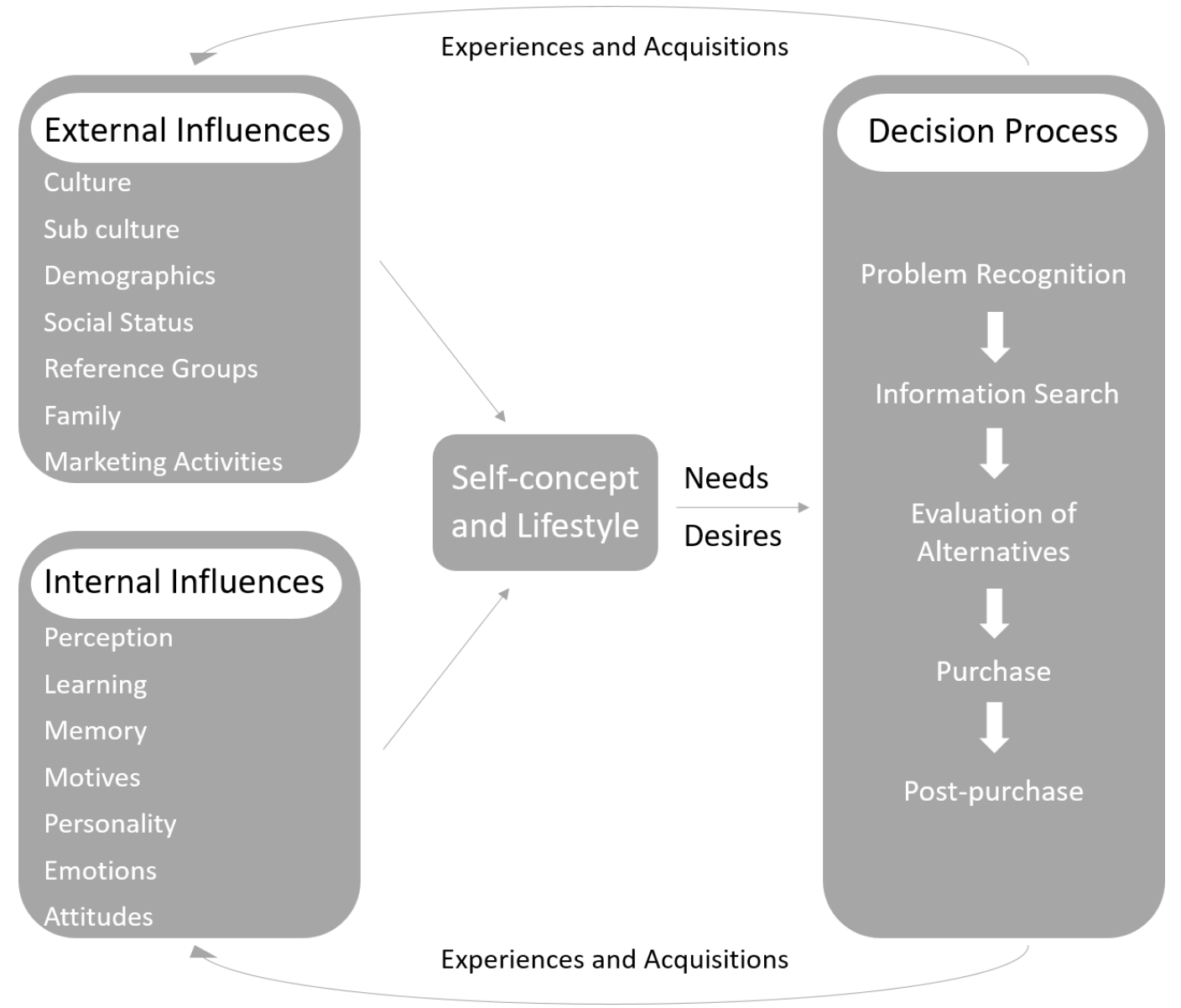

Source: Hawkins and Mothersbaugh, 2010

\section{Purchasing Decision Process}

Part of the consumer behaviour model is the purchasing decision process. Engel, Kollat and Blackwell (1978) described it in five different steps, later integrated in Hawkins and Motherbaugh's model: problem or need recognition; information search; evaluation of alternatives and selection; purchase and post-purchase evaluation.

\section{Problem or Need Recognition}

Problem or need recognition is the result of a discrepancy between the way an individual perceives his or her feelings at the present time and the way they want to feel (Mostert, 2002; Tan, 2010). This discrepancy is a consequence of the combination of internal factors, such as one's own beliefs, personality or perception, and external factors, such as marketing activities, culture, social class, reference groups and lifestyle (Sandhusen, 2000; Punj \& Srinivasan, 1992; Łatuszyńska, Furaiji \& Wawrzyniak, 2012). Choi, Kim, and Kim (2007) studied the consumer behaviour of university students and Beijing and found out that the main reason that leads consumers to buy cosmetics is the dissatisfaction with their current products. However, different contexts and products may lead consumers to recognise a problem or need under different circumstances. For example, for U.S. consumers of home 
furniture "problem recognition is likely to occur when a consumer experiences a significant life change, such as getting married, purchasing a first home, having children, or downsizing due to retirement and/or children leaving home" Ponder (2013, p.9).

\section{Information Search}

At this stage, consumers perform an internal search from past personal experiences to find satisfactory solutions for the problem. If no solution is found, they will proceed to an external search (Mostert, 2002) that can be based on impersonal sources (e.g. mass media), marketer sources (e.g. advertising and point-of-sale contacts) and personal sources (e.g. friends, peer groups and family) (Tan, 2010). Information from personal sources has been found to be particularly influential in consumer decisionmaking and consumers often rate personal sources as the most important source of information (Katona \& Mueller, 1955; Price \& Feick, 1984; Robertson, 1971, cited in Seo, 2002, p.36). Choi, Kim and Kim (2007) found that the main information sources used by university students in Beijing before buying cosmetics are recommendations from friends and colleagues and beauty magazines. Reference groups, such as friends and family, are also an important source of information in different contexts. For example, when selecting a coffee brand to buy, the most important sources of information for respondents in Finland were family, friends and neighbours (Lautiainen, 2015).

Brand awareness increases the probability of the brand being included in the consumers' evoked set (Cobb-Walgren, Ruble \& Donthu, 1995). Referencing to the argument by Sasmita and Mohd Suki (2015), which reviewed studies of Huang and Sarigöllü (2012) and Pouromid and Iranzadeh (2012), consumers' brand awareness influences the brands' preference.

\section{Evaluation and Selection of Alternatives}

Evaluation of alternatives is affected by internal factors like beliefs and attitudes and external factors such as previous shopping and consumption experiences (Tan, 2010). Hawkins and Mothersbaugh (2010) describe three types of choice: affective choice, which evaluates a product based on how it will make the user feel; attitude-based choice, which involves emotions and impressions; and attribute-based choice, which requires knowledge about the product's attributes to compare different brands. According to Choi, Kim and Kim (2007), the main factors why university students in Beijing choose a cosmetic product over a similar alternative are function, effects and price. Other important criteria include brand image, colour, fragrance, convenience of purchase, feeling when using the product and advertisement. However, some of these criteria may become secondary or irrelevant when purchasing different products. For painkiller consumers in the UK, safety is a "crucial evaluative dimension" (Paddison \& Olsen, 2008, p.297). Nonetheless, similarly to cosmetic products, the effect of the product (rapidity of painkiller diffusion) is also important when evaluating and selecting alternatives. 


\section{Purchase}

A purchase occurs either in a retail-type environment or through in-house shopping (Mostert, 2002). According to a study from The Henley Center (1996, cited in Connolly \& Davison, 1996), 73\% of purchasing decisions are made in-store. Based on the work of Arkes et al. (1994), which was later cited by Janakiraman et. al. (2006), and quoted in Tendai and Crispen (2009, p.104), unexpected price discount results in higher expressions of willingness to pay for unrelated discretionary items. Although some customers enjoy helpful and friendly shop assistants, a significant number also report negative shop experiences due to overly aggressive assistants, bad service and lack of product knowledge (Jones, 1999; Yip, Chan and Poon, 2012). The findings of Hou, Wu and $\mathrm{Hu}$ (2013) also support that consumers need individual space and may feel unhappy if sales personnel are excessively attentive. Choi, Kim and Kim (2007) found that female university students of China chose a store mostly based on its reputation and good atmosphere and service. For U.S. consumers of home furniture, however, store characteristics are not important, and they tend not to be loyal to any specific furniture store (Ponder, 2013). Product characteristics play a more important role, as these "consumers are willing to shop at multiple outlets to find a piece of furniture that best satisfies their needs" (Ponder, 2013, p.27).

\section{Post-Purchase}

If the customer is satisfied with the purchased product, the result can be increased use, repeated purchases, brand loyalty or positive word of mouth. If the product fails to satisfy the customer's needs, they may take no action at all, may switch products, brands, or engage in negative word of mouth (Hawkins \& Mothersbaugh, 2010). Choi, Kim and Kim (2007) found out that, when not satisfied with a cosmetic product, most Chinese consumers exchange it at the place of purchase, showing a rather active dissatisfactory attitude. This is confirmed by a study from Lee (2005), which showed that $51.9 \%$ of dissatisfied consumers of imported health food products in China choose to present a formal complaint, while $48.1 \%$ carry out a non-formal complaint, "in which they either share their negative attitude with their friends and family members or they internalised the negative attitude into their personal experience" (Lee, 2005, p.51).

For marketers, the ideal scenario is to develop loyal customers, because they are emotional attached to the brand, are likely to recommend it and are less subject to competitors' actions (Hawkins \& Mothersbaugh, 2010). 


\section{Methodology}

The primary purpose of this study was to understand the factors that Swiss and Chinese consumers considered in cosmetic purchasing throughout the 5 steps of the purchasing process in two different areas of each country. This way, it was possible to understand the regional differences within each country and the possible cultural gap between consumer groups in the two countries. The research followed an inductive qualitative approach, as the objective of the research was to acquire understanding of human behaviour and the reasons of occurrence of that behaviour (Khalid, Hilman \& Kumar, 2012, p.16).

A test incorporating projective questions was delivered online in September and October 2016 in the German-speaking and French-speaking Switzerland in person during October 2016 in Shanghai and Harbin. The test was developed in English and translated into Mandarin, German and French by native speakers. A back-to-back translation was done, to ensure content accuracy. Prior to participation, respondents gave their consent to participate in a voluntary basis and were given the right to withdraw from the participation during the research. Privacy and anonymity of all respondents were guaranteed, as no personal identifying information was collected.

The test was structured based on the five steps of the purchasing decision process. Projective tests derive from psychotherapy and are based on the idea that respondents are more willing to project their feelings onto others, animals or cartoons, than they are to attribute these feelings to themselves (Belk, Fischer \& Kozinets, 2013). In this study, projective techniques used asked respondents to indicate the first word or thought that came to their minds; construct a story from a stimulus picture; describe their feelings if a brand was no longer available; and complete sentences, stories, an argument, a conversation and a dialogue. A dialogue completion was used as in the following example, in order to understand what information sources consumers of cosmetics trust most.

\section{Figure II: Example of Dialogue Completion for Swiss Consumers}

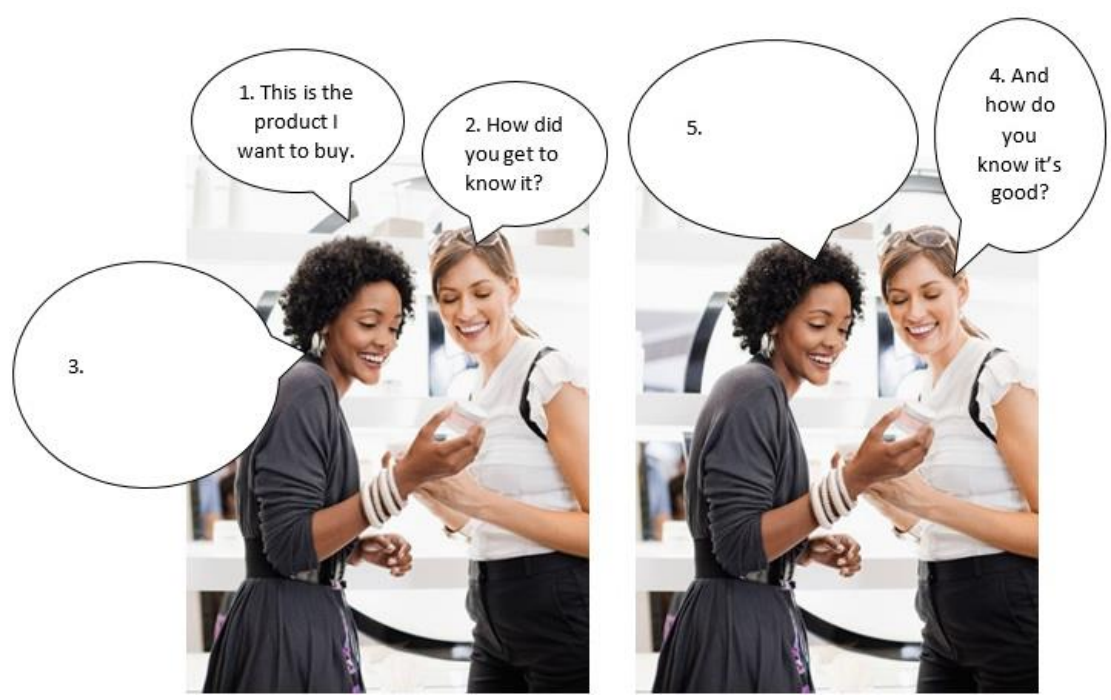

Source: Modified by author from http://wdy.h-cdn.co/assets/cm/15/10/54f5f5ffe41f3_-_womenshopping-for-makeup-mdn.jpg 
Figure III: Example of Dialogue Completion for Chinese Consumers

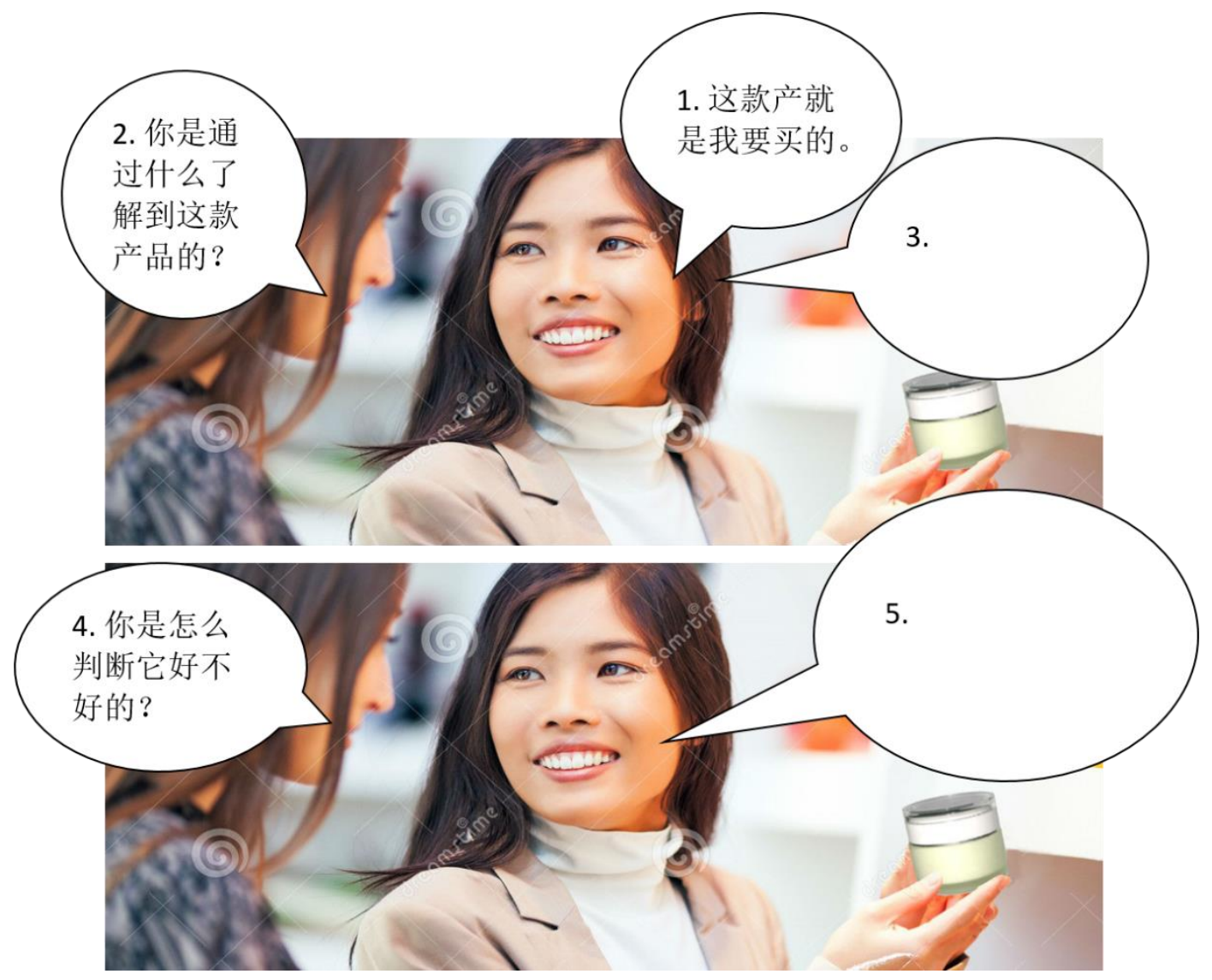

Source: Modified by author from https://www.dreamstime.com/stock-photography-women-buyingsoap-two-smiling-shop-image30992822

Images showing people ethnically more similar to respondents were used in each locale, in order to make it easier for them to project themselves into the situation and provide more reliable answers. Since the focus of the present research is purchasing decision rather than brand recognition or perception, no particular brands were mentioned, giving respondents the freedom to talk about any brand.

A non-random convenience sample of 65 female cosmetic consumers aged 20 to 39 was selected, since this age group is the most relevant for the Chinese market (Fung Business Intelligence Centre, 2015) and the second most relevant in Switzerland (Zulauf, 2002). Respondents came from diverse backgrounds (students, low-skilled workers and high-skilled workers) to represent the broad characteristics of the buying public. The sampling profile included twelve respondents from French-speaking Switzerland, fourteen respondents from German-speaking Switzerland, twenty-three respondents from Shanghai and sixteen respondents from Harbin.

Data was analysed using a thematic analysis, a method for identifying, analysing and reporting patterns (themes) within data, organising and describing it in detail. It is considered free from any pre-existing theoretical framework, being used within different frameworks (Braun \& Clarke, 2006). The present research follows a realist approach as opposed to constructionist or contextualist, as it aims to find out, examine 
and compare the "experiences, meanings and the reality of participants" (Braun \& Clarke, 2006, p.9).

Different themes were defined for each step of the purchasing process. Table I provides an example of how themes were generated. The complete coding process is available from the authors.

Table I: Example of Coding Process

\begin{tabular}{|c|c|c|c|c|}
\hline & Initial codes & Potential themes & $\begin{array}{l}\text { Changes in } \\
\text { themes }\end{array}$ & Final themes \\
\hline \multicolumn{5}{|l|}{ Shanghai } \\
\hline \multirow[t]{4}{*}{$\begin{array}{l}\text { Problem } \\
\text { recognition }\end{array}$} & $\begin{array}{l}\text { - Others' opinion } \\
\text { - Coming across a } \\
\text { prettier woman } \\
\text { - Not popular } \\
\text { among friends } \\
\text { - Special event } \\
\text { - New job }\end{array}$ & - External factors & - External factors & \multirow[t]{4}{*}{$\begin{array}{l}\text { - The } \\
\text { importance of } \\
\text { others' } \\
\text { opinion }\end{array}$} \\
\hline & - Self-awareness & - Internal factors & & \\
\hline & - Skin problems & - Skin problems & & \\
\hline & $\begin{array}{l}\text { - Want to look } \\
\text { pretty }\end{array}$ & - Pursuit for beauty & & \\
\hline
\end{tabular}

The comparison of the different themes obtained allowed classifying the behaviour variation as: minor, when respondents in both groups share similar ideas; significant, when additional ideas from one group are not present in the other, but core ideas are shared; and fundamental, when the core ideas are completely different. In a first phase, findings from different areas of each country were compared, to understand how regional differences affect the purchasing decision. In a second phase, findings of consumers in Switzerland and China were compared, in order to find out the cultural gap between the two broad groups of consumers.

\section{Results}

\section{French-Speaking Area of Switzerland}

Consumers in French-speaking Switzerland tend to use cosmetics because of skin problems and relate them to health and well-being:

\section{F-4: "Cosmetics are part of a ritual for health and well-being"; F-11: "She saw a wrinkle".}

Although they will listen to recommendations from personal sources, their own experience is the most important source of information. Moreover, the use of samples and testers seems to be relatively common in the region.

\section{F-1: "I learn about the good quality of a product when friends tell me about their experiences/preferences. Anyway, I will buy it, test it, if it is not good, I will not buy it again"; \\ F-5: "I know the product is good because I tried a sample".}


French brands are the most recognised among respondents, mostly because they are currently using them and like the quality or they remember seeing advertisements recently. However, they prefer to buy French brands of skin-care products and American brands in the make-up segment, mostly due to own use and proven results.

When choosing between similar alternatives of products, they tend to look at attributes such as low price, good smell, high efficacy and bio products.

F-6: "It's the most effective";

F-12: "It's cheaper".

They will consider recommendations of shop assistants for a different product, but tend to take it as another information source rather than an absolute truth. They will carry out more research and compare it with the product they originally wanted to buy.

F-1: "She will maybe take the assistant's opinion into account, however if after a first experience it does not quite fit her expectations, she will buy the other product in order to compare and verify her research";

F-8: "She verifies the information and buys the one that really suits her best".

However, respondents will seize the opportunity to buy extra products in in-store sales, without necessarily knowing the products on sale, or needing them at that moment.

F-4: "She leaves the store with many extra products";

F-7: "She bought other products because they are cheaper".

If not happy with a product they bought, many respondents will not take any active action besides throwing it away or leaving aside, but some will complain and not recommend it to other people.

F-5: "I will not use it anymore nor recommend it to anyone";

F-9: "I will just put it aside".

On the other hand, if they like a product, they tend to be very loyal customers, showing feelings of sadness and disappointment if their favourite brand disappears.

\section{German-Speaking Area of Switzerland}

Internal factors, such as bad feelings about their body hygiene or skin issues like dryness and pimples tend to drive problem recognition.

G-7: "My skin is dry; I am not happy";

G-9: "We should take care of our hygiene, health and compatibility".

However, psychological and social issues were also identified as a reason to buy cosmetics. 


\section{G-8: "Cosmetics make you feel more confident"; \\ G-13: "She experienced social discrimination due to beauty reasons";}

Most consumers will base their information search on their previous experiences or on personal sources. They are willing to buy new products, as long as they are recommended by someone close to them.

\section{G-1: "A friend told me about it. She has been using it for a long time and is happy with it"; \\ G-6: "I buy what I always bought or something that a friend recommended $m e "$,}

Consumers are mostly aware of French and German brands, due to longstanding use and American make-up brands, due to their quality. When buying cosmetics, they prefer German and French brands, due to frequent use.

When deciding between similar alternatives, most respondents will base their choice mainly on attributes such as cheaper price, a high quality/price ratio and product specifications, but also on how attractive the outlook of the product is.

G-3: "It has a benefit that the other product doesn't have";

G-6: "It's cheaper".

Very few respondents are not influenced by in-store environment. They will buy a different product suggested by the sales assistant if she or he presents good and professional arguments.

G-8: "If the salesperson is professional, she might change her mind",

G-14: "It depends on whether the arguments of the saleswoman are convincing or not. If they are, then she changes the product. Otherwise she thanks her for the advice and keeps her selection".

They will buy extra products at in-store sales, but only if it is something they also need, regularly use, or expensive products that are not usually on sale, like sunscreen.

G-1: "She buys the product she intended. If a brand she likes is also on sale, she will maybe buy a second one";

G-8: "I will get more products I regularly use because now they are all on sale".

If not happy with a product, a few respondents mentioned they would complain and not recommend it, but most would not take active actions.

G-4: "I will throw it away";

G-6: "I will never buy it again, and will write a bad review";

In general, consumers proved to be very loyal towards brands they use often, when they showed sad feelings if a brand was to disappear. 


\section{Comparison of the Purchasing Process of Consumers from French and German- Speaking Switzerland}

The table below summarises the themes that arouse from consumers' responses. Overall, in both regions, purchasing processes are quite similar, the only significant difference being registered in the problem recognition step.

Table II: Themes and Quotes from Consumers in Switzerland

\begin{tabular}{|c|c|c|c|c|c|c|}
\hline \multicolumn{2}{|c|}{$\begin{array}{r}\text { Purchasing } \\
\text { steps }\end{array}$} & $\begin{array}{l}\text { Problem } \\
\text { Recognition }\end{array}$ & $\begin{array}{l}\text { Information } \\
\text { Search }\end{array}$ & $\begin{array}{l}\text { Alternative } \\
\text { Evaluation }\end{array}$ & Purchase & $\begin{array}{l}\text { Post- } \\
\text { purchase }\end{array}$ \\
\hline \multirow[b]{2}{*}{$\begin{array}{l}\text { French- } \\
\text { speaking }\end{array}$} & $\underset{\mathscr{E}}{\stackrel{\Xi}{E}}$ & $\begin{array}{l}\text { Skin problems } \\
\text { and well being }\end{array}$ & $\begin{array}{l}\text { Importance of } \\
\text { samples and } \\
\text { testers }\end{array}$ & $\begin{array}{l}\text { Selection } \\
\text { based } \\
\text { on product } \\
\text { attributes }\end{array}$ & $\begin{array}{l}\text { In-store } \\
\text { influences } \\
\text { taken into } \\
\text { consideration }\end{array}$ & $\begin{array}{l}\text { Some active } \\
\text { complaining } \\
\text { behaviour and } \\
\text { loyalty }\end{array}$ \\
\hline & 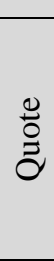 & $\begin{array}{l}\text { F-4: "Cosmetics } \\
\text { are part of a } \\
\text { ritual for health } \\
\text { and well-being" }\end{array}$ & $\begin{array}{l}\text { F-5: "I know the } \\
\text { product is good } \\
\text { because I tried a } \\
\text { sample" }\end{array}$ & $\begin{array}{l}\text { F-12: "It's } \\
\text { cheaper" }\end{array}$ & $\begin{array}{l}\text { F-8: "She } \\
\text { verifies the } \\
\text { information } \\
\text { and buys the } \\
\text { one that really } \\
\text { suits her best" }\end{array}$ & $\begin{array}{l}\text { F-5: "I will } \\
\text { not use it } \\
\text { anymore nor } \\
\text { recommend it } \\
\text { to anyone" }\end{array}$ \\
\hline \multirow[b]{2}{*}{$\begin{array}{l}\text { German- } \\
\text { speaking }\end{array}$} & $\underset{\stackrel{\mathscr{\Xi}}{\mathscr{E}}}{\stackrel{\mathscr{E}}{E}}$ & $\begin{array}{l}\text { Skin problems } \\
\text { and social issues }\end{array}$ & $\begin{array}{l}\text { Own experience } \\
\text { and personal } \\
\text { sources }\end{array}$ & $\begin{array}{l}\text { Selection } \\
\text { based } \\
\text { on product } \\
\text { attributes }\end{array}$ & $\begin{array}{l}\text { In-store } \\
\text { influences } \\
\text { taken into } \\
\text { consideration }\end{array}$ & $\begin{array}{l}\text { Some active } \\
\text { complaining } \\
\text { behaviour and } \\
\text { loyalty }\end{array}$ \\
\hline & $\stackrel{\frac{\pi}{0}}{2}$ & $\begin{array}{l}\text { G-13: "She } \\
\text { experienced } \\
\text { social } \\
\text { discrimination } \\
\text { due to beauty } \\
\text { reasons" }\end{array}$ & $\begin{array}{l}\text { G-8: "I buy } \\
\text { products I } \\
\text { already tried, or } \\
\text { somebody } \\
\text { recommended } \\
\text { them" }\end{array}$ & $\begin{array}{l}\text { G-6: "It's } \\
\text { cheaper" }\end{array}$ & $\begin{array}{l}\text { G-8: "If the } \\
\text { salesperson is } \\
\text { professional, } \\
\text { she might } \\
\text { change her } \\
\text { mind" }\end{array}$ & $\begin{array}{l}\text { G-6: "I will } \\
\text { never buy it } \\
\text { again, and will } \\
\text { write a bad } \\
\text { review" }\end{array}$ \\
\hline \multicolumn{2}{|c|}{$\begin{array}{l}\text { Intra-country } \\
\text { Purchasing } \\
\text { Behaviour } \\
\text { Variation }\end{array}$} & Significant & Minor & Minor & Minor & Minor \\
\hline
\end{tabular}

\section{Harbin, China}

Some external concerns about image are present in consumers' minds:

H-2: "I came across a boy I like, or I have an interview",

H-9: "Oh! I don't look good! Or "someone said: Look at your face! Look at your hair! - It's time to do something";

However, respondents from Harbin are mostly concerned about their skin and use cosmetics to make sure it is in the best possible condition.

H-11: "The sun is very strong, I need to buy sunscreen so that my skin doesn't become black";

H-12: "My skin is flaccid, because I haven't used my cosmetics continuously, no rules, whenever I remembered. I'm already 34 years old, I need professional care, to take good care of myself before I become old". 
When gathering information about a product, respondents will mostly trust their own experience with the product, or, if they have never used or tried it, they will trust personal sources.
H-4: "I don't buy products that I haven't tried or that I don't know, usually if the recommendations and reviews are very good, then I go buy it; I don't buy completely new products";
H-10: "I used it myself, or a friend recommended it".

They are mostly aware of French brands, due to their good reputation or a particularly famous product (e.g. Yves Saint Laurent's lipstick) and Korean and American brands, due to frequent use by the respondents. But when buying, respondents prefer Korean and Japanese brands due to "good feelings" and "good moisturising", and American brands due to longstanding use.

If selecting between similar alternatives, the most important criteria is skin compatibility. Other criteria are cheaper price and package outlook.

\section{H-4: "It's more suitable for my skin"; \\ H-11: "Its moistures better";}

Consumers are aware that shop assistants sometimes get commissions from selling certain products, but still regard them as cosmetic professionals and sometimes will follow their advice.

H-7: "She trusts her research more than the recommendation of the sales assistant. If she hadn't done any research, she would consider, but since she researched a lot, she will stick to her own product. Because their recommendations are maybe related to their earnings";

Regarding in-store sales, respondents will take advantage of larger sales, but most of them will only buy from the sale if it is something they are in need of. Many agree they should not buy something that they do not know just because it is on sale.

H-4: "If it suits me or I need it, I would buy extra products from the sale";

H-15: "She buys the original product and only buys more if she already knows the products".

Respondents are also suspicious regarding very large sales (e.g. whole store 50\% off).

H-15: "I would not buy face-care products, only hand-care".

After the purchase, if they are not satisfied with a product, they will take no active actions complaining about it.

H-1: "I would give it to my mother";

H-2: "I would throw it away". 
Furthermore, they do not show loyal feelings towards any brand.

H-2: "No feelings, I would change, I am happy to try new ones";

H-14: "I would just change. I don't have to always buy that brand".

Many also believe that when they have been using a brand for too long, they will stop seeing results, and therefore should change to another brand.

\section{Shanghai, China}

When considering buying cosmetics, respondents in Shanghai place a lot of importance on external factors, such as other people's opinion about the way they look. They mostly relate cosmetics to beauty, and that is the main reason they buy these products.

S-16: "She's starting her career and needs cosmetics to make her look more professional".

S-19: "Her boyfriend used to tell her that even without make up she looked beautiful. Now he told her without make up she doesn't look good".

Besides their own experience and close personal recommendations, a particularly trendy source of information are online reviews and the opinion of beauty bloggers.

S-7: "My friends recommended it; I check information on sites like WeChat or WeiBo";

S-11: "I saw some information on blogs, so I would choose it directly, I trust their reviews",

Respondents are mostly aware of French and American brands, mainly due to the popularity of one specific product (e.g. Chanel and Yves Saint Laurent's lipstick) and current trends.

\section{S-11: "Currently there's an online trend in China, which is if your boyfriend does not buy you an Yves Saint Laurent lipstick, it means he does not love you”.}

When purchasing, they prefer Korean and Japanese skin-care products, as they see them as more suitable for Chinese skin, but prefer European and American make-up brands, because of their stronger colour.

Besides a cheaper price and good quality, more subjective impressions such as the design of the package or brand reputation are often the decisive criteria to choose between similar alternatives.

S-11: "I choose the famous brand - it's a safer choice";

S-12: "It seems to be more beautiful; she prefers the colour". 
Respondents are very suspicious about store assistants and do not change their minds when given a different recommendation, as they consider that they recommend the product that is most convenient to them and not necessarily the one that best suits the customer.

\section{S-11: "Shop assistants are not trustworthy. In China, most times they} recommend you products that they want to sell and not the ones that are suitable for you. She should trust her own research";

S-20: "Her job is to sell, if she sells more, she gets more money. She doesn't recommend the one that is most suitable, but the one she will get more money from selling".

Customers also adopt a defensive approach to in-store sales. Smaller sales are not popular and do not make them change their minds. Larger sales are more popular, but they will only buy products that they already know and that they require. They are concerned about quality issues on larger sales.

S-15: "If I don't know these products, I would ignore the sale";

S-16: "I would check, but there would be a reason behind this kind of sales. If products are of good quality, I would buy extra".

If not satisfied with a product, consumers will not take any active complaining action.

S-15: "I will throw it away";

S-23: "If it's a face product, I will use it for hands or body".

Although many respondents are not particularly loyal towards any brand, some are starting to see value in some brands, especially those that help to improve particular conditions, such as dry skin.

S-5: "I don't have any feelings, I would just change brands, it's easy to find similar brands";

S-8: "What to do? Who can save my skin? Finding an equivalent brand is not easy".

\section{Comparison of the Purchasing Process of Consumers from Harbin and Shanghai}

The table below summarises the themes that best describe consumers' purchasing decision process. Overall, the purchasing process of consumers from both regions are rather different, with similarities seen in the purchase and post-purchase steps. 
Table III: Themes and Quotes from Consumers in China

\begin{tabular}{|c|c|c|c|c|c|c|}
\hline \multicolumn{2}{|c|}{$\begin{array}{ll}\text { Purchasing } \\
\text { steps } \\
\text { Cities }\end{array}$} & $\begin{array}{l}\text { Problem } \\
\text { Recognition }\end{array}$ & $\begin{array}{l}\text { Information } \\
\text { Search }\end{array}$ & $\begin{array}{l}\text { Alternative } \\
\text { Evaluation }\end{array}$ & Purchase & $\begin{array}{l}\text { Post- } \\
\text { purchase }\end{array}$ \\
\hline \multirow[b]{2}{*}{ Harbin } & 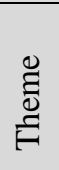 & $\begin{array}{l}\text { Need to } \\
\text { protect the } \\
\text { skin }\end{array}$ & $\begin{array}{l}\text { Not willing to } \\
\text { try completely } \\
\text { new products }\end{array}$ & $\begin{array}{l}\text { Most } \\
\text { suitable for } \\
\text { the skin }\end{array}$ & $\begin{array}{l}\text { Distrust for large } \\
\text { sales and in-store } \\
\text { recommendations }\end{array}$ & $\begin{array}{l}\text { No active } \\
\text { complaining } \\
\text { behaviour and } \\
\text { not loyal }\end{array}$ \\
\hline & $\frac{0}{0}$ & $\begin{array}{l}\text { H-12: "My } \\
\text { skin is flaccid, } \\
\text { because I } \\
\text { haven't used } \\
\text { my cosmetics } \\
\text { continuously } \\
\text { (...)" }\end{array}$ & $\begin{array}{l}\text { H-10: "I used it } \\
\text { myself, or a } \\
\text { friend } \\
\text { recommended } \\
\text { it" }\end{array}$ & $\begin{array}{l}\text { H-4: "It's } \\
\text { more } \\
\text { suitable for } \\
\text { my skin" }\end{array}$ & $\begin{array}{l}\text { H-15: "She buys } \\
\text { the original } \\
\text { product and only } \\
\text { buys more if she } \\
\text { already knows the } \\
\text { products" }\end{array}$ & $\begin{array}{l}\text { H-14: "I } \\
\text { would just } \\
\text { change. I don't } \\
\text { have to always } \\
\text { buy that } \\
\text { brand" }\end{array}$ \\
\hline \multirow[b]{2}{*}{ Shanghai } & 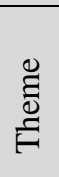 & $\begin{array}{l}\text { Importance of } \\
\text { beauty and } \\
\text { others' } \\
\text { opinion }\end{array}$ & $\begin{array}{l}\text { Popularity of } \\
\text { online reviews } \\
\text { and opinion } \\
\text { makers }\end{array}$ & $\begin{array}{l}\text { Subjective } \\
\text { aspects }\end{array}$ & $\begin{array}{l}\text { Distrust for large } \\
\text { sales and in-store } \\
\text { recommendations }\end{array}$ & $\begin{array}{l}\text { No active } \\
\text { complaining } \\
\text { behaviour and } \\
\text { some loyalty }\end{array}$ \\
\hline & $\stackrel{0}{0}$ & $\begin{array}{l}\text { S-19: "Her } \\
\text { boyfriend used } \\
\text { to tell her that } \\
\text { even without } \\
\text { make up she } \\
\text { looked } \\
\text { beautiful. Now } \\
\text { he told her } \\
\text { without make } \\
\text { up she doesn't } \\
\text { look good" }\end{array}$ & $\begin{array}{l}\text { S-7: "My } \\
\text { friends } \\
\text { recommended } \\
\text { it, I check } \\
\text { information on } \\
\text { sites like } \\
\text { WeChat or } \\
\text { WeiBo" }\end{array}$ & $\begin{array}{l}\text { S-12: "It } \\
\text { seems to be } \\
\text { more } \\
\text { beautiful, } \\
\text { she prefers } \\
\text { the colour" }\end{array}$ & $\begin{array}{l}\text { S-20: “(...) She } \\
\text { doesn't recommend } \\
\text { the one that is most } \\
\text { suitable, but the } \\
\text { one she will get } \\
\text { more money from } \\
\text { selling”. }\end{array}$ & $\begin{array}{l}\text { S-5: "I don't } \\
\text { have any } \\
\text { feelings, I } \\
\text { would just } \\
\text { change brands, } \\
\text { it's easy to } \\
\text { find similar } \\
\text { brands"; }\end{array}$ \\
\hline \multicolumn{2}{|c|}{$\begin{array}{c}\text { Intra-country } \\
\text { Purchasing } \\
\text { Behaviour } \\
\text { Variation }\end{array}$} & Fundamental & Fundamental & Significant & Minor & Minor \\
\hline
\end{tabular}

\section{Comparison of the Purchasing Process of Consumers from Switzerland and} China

It was evident that the purchasing processes of consumers in Switzerland is very similar, but those of consumers in China differ quite a lot. For that reason, it is not possible to group Harbin and Shanghai together, and it is necessary to draw a comparison between the two individual Chinese cities and Switzerland.

\section{Problem Recognition}

In Switzerland and Harbin, respondents use cosmetics due to personal and internal reasons, such as skin issues and well-being, but also social and psychological reasons, such as lack of confidence or social discrimination. In Shanghai, the predominant reasons to use cosmetics are external, but more related with beauty and other people's opinion, rather than feeling good about one's self. 


\section{Information Search}

Basing their search on own experience and close personal sources is common to all consumer groups. However, in Switzerland and Harbin respondents are more reluctant to buy products that they have never tried before, whereas in Shanghai there is an increasing popularity of online reviews and beauty bloggers as sources of information.

\section{Evaluation of Alternatives}

Consumers in Switzerland and Harbin tend to base their evaluation on product attributes such as cheaper price, better smell or product characteristics. Furthermore, consumers in Shanghai are also influenced by attitudes such as the reputation of the brand or the look of the package.

\section{Purchase}

Respondents from Switzerland find in-store sales and recommendations from sales personnel valuable, being more easily influenced by them than those in Harbin and Shanghai. In both Chinese cities, respondents showed a high degree of distrust towards in-store stimuli, both recommendations and sales, and rely much more on their own research. The latter finding was of particular interest, as it highlights an area for further research, with immediate importance to brands and retailers.

\section{Post-Purchase}

Consumers in Switzerland tend to value and become loyal to a brand if they like it, while in China that only happens in Shanghai if the consumer has a specific issue that some particular brand is able to attenuate. Regarding complaining behaviour, consumers in Switzerland are more active in complaining if not happy with a product than those in Harbin and Shanghai, where no complaining intentions were registered.

The table below summarises the variation on the purchasing behaviour between Switzerland, Harbin and Shanghai. 
Table VI: Variation on the Purchasing Behaviour Between Consumers from Switzerland, Harbin and Shanghai

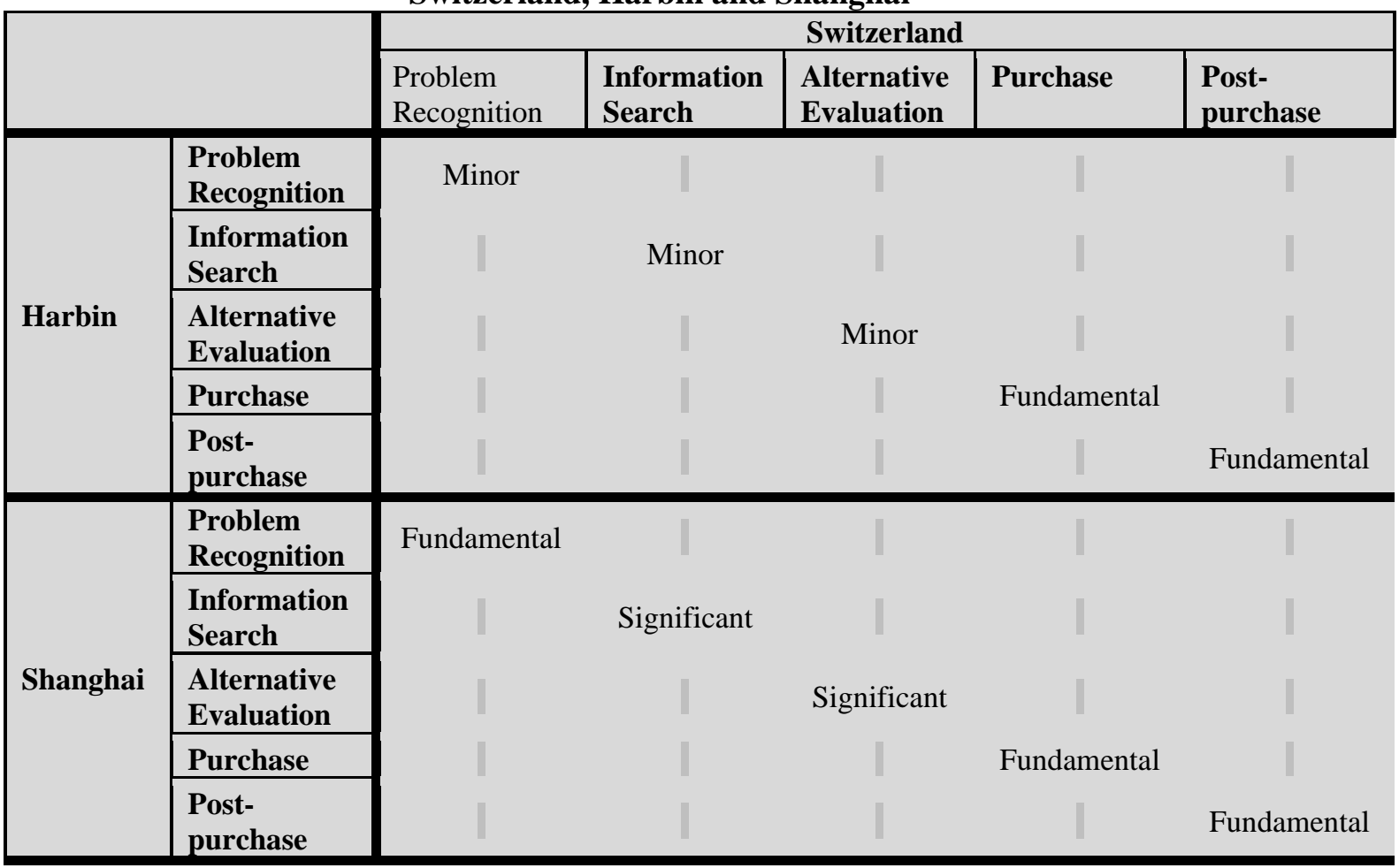

\section{Conclusion}

One of the first conclusions of this research is that it is not possible to group the purchasing behaviour of cosmetic consumers of different cities under one individual country, particularly in China. Switzerland is a relatively small country and shows small regional variations on the purchasing behaviour. However, as one of the world's largest countries, regional differences in terms of economy and attitudes are too accentuated to allow a generalisation of the purchasing behaviour of cosmetics in China.

Consumers from the four regions mentioned similar aspects in several purchasing steps, such as the awareness for French brands or the evaluation based on the price/quality ratio. However, the most illustrative factors that best described each purchasing step were most times different. Stronger similarities are seen between Switzerland and the city of Harbin in the "need recognition", "information search" and "evaluation of alternatives" phases. The two regions have similar needs when it comes to cosmetics, mainly related to health and well-being, are influenced by similar sources of information, such as own experience and personal sources, and base their evaluation of alternatives on the same factors, such as price and skin compatibility. Major differences are seen in the "purchase" and "post-purchase" phases, due to variances in in-store influences, loyalty towards cosmetic brands and complaining behaviour. 
This study did not find significant similarities between the purchasing process of consumers in Switzerland and Shanghai. Respondents have very different perspectives on the motives for using cosmetics, with consumers in Shanghai being mostly concerned with looking beautiful. When gathering and comparing product information, Swiss consumers are not as influenced by impersonal sources and impressions about brands as those in Shanghai. During in-store purchase, Swiss consumers are more influenced by in-store environment and prefer Western rather than Asian brands. Regarding post-purchase behaviour, Swiss consumers show more brand loyalty and have a more active complaining behaviour than consumers from Shanghai.

\section{Theoretical Implications}

The present study followed the five steps of the purchasing process and provided useful findings for each of them. The findings supported Sandhusen (2000) in confirming that problem recognition derives from a combination of internal and external sources.

Personal sources are in most cases the most reliable information sources for consumers, supporting Katona \& Mueller (1955), Price \& Feick (1984) and Robertson (1971), cited in Seo (2002, p.36). However, regarding brand awareness, the present findings do not match those of Huang and Sarigöllü (2012) and Pouromid and Iranzadeh (2012) as cited in Sasmita and Mohd Suki (2015), since the most recognised brands are often not the most purchased.

Of the three aspects mentioned by Hawkins and Mothersbaugh (2010) in evaluating alternatives (attitude-based choice, attribute-based choice and affective choice), the most prominent one identified by this study among all groups of consumers was the attribute-based choice. This type of evaluation was based on attributes such as price, smell or price/quality ratio. Attitude-based choice was present in Shanghai, where some consumers base their choice on impressions such as advertisements or brand reputation.

In the "Purchase" step, the review of Tendai and Crispen (2009) based on the work of Arkes et al. (1994) and subsequently cited by Janakiraman et. al. (2006) stated that price discounts result in a higher willingness to buy extra products. However, the present research has not confirmed this information, as it depends on the level of discount and attitudes of consumers. Regarding sales personnel's recommendations, both the findings of Jones (1999) and Hou, Wu and Hu (2013) were confirmed, since consumers' reactions may vary depending on multiple factors.

Finally, in the "Post-purchase" step, this research registered all the aspects mentioned by Hawkins and Mothersbaugh (2010): when not happy with a purchase, some customers take no action, others switch products or brands and some engage in negative word of mouth. 


\section{Limitations and Future Academic Research}

This study has taken a first step towards understanding the behaviour of groups of Chinese and Swiss consumers. It did not focus on any particular cosmetic categories and provided an overview of the purchasing decision process, not focusing on any particular step. In general, the behaviour of consumers depends on many abstract factors that may not be instantly evident and are only visible when going deeper into small details. Therefore, further research that focuses on particular cosmetic categories and/or on particular purchasing phases is needed, to which the present research provides a good basis.

Furthermore, the results have opened an additional research area in investigating variations in interpersonal and system trust especially in the purchase process for Chinese consumers or at least female Chinese cosmetic consumers aged 20 to 39 . Both trust development linked to knowledge of the product and trustworthiness linked to perceptions of ability, benevolence and integrity are areas which could profitably be investigated further.

\section{Practical Implications for Asian Business}

The findings of this study provide valuable information for cosmetic manufacturers wanting to enter or change their marketing strategy in the Chinese or Swiss market, but particularly for Western manufacturers or brands that are already present in Switzerland and aim to enter or change their strategy in China to better reach female cosmetic consumers aged 20 to 39 .

According to the present study, the first issue to address is that a brand's strategy should be adjusted by region in China. There are significant differences in the purchasing behaviour between Shanghai and Harbin, which is a tier 1 and tier 2 city respectively. While consumers interviewed in Shanghai and Harbin shared a distrust for large sales and in-store recommendations and neither sample engaged significantly in active complaining behaviour or were automatically loyal to a given brand; there were significant differences in their responses in the Problem Recognition, Information Search and Alternative Evaluation. While in Harbin respondents focused more on the efficacy of the product, Shanghai consumers reported a far stronger response to opinion-makers and influencers as well as the need to fulfil the expectations of their peers. Even stronger variations may be found when analysing the behaviour of consumers from tier 3 and tier 4 cities.

Regarding the pre-purchase behaviour, advertisements seem to work in the four regions as a trigger to buy cosmetics, as source of information and basis for evaluation of alternatives. However, it has been losing ground to other tactics. In Switzerland, marketers should consider the importance of giving out samples and having testers available, as well as sales and new products launchings. Furthermore, consumers in Switzerland enjoy in-store sales and shop assistants' recommendations.

In Harbin, brands should consider how important skin health is for consumers and draw attention to features related to that on their products. In Shanghai, the importance of promotions on social media, user generated content and the impact of 
influencers, KOLs etc. should not be neglected, since it is one of the main communication channels between the brand and consumers and it is where users share their experiences with products.

In Shanghai and Harbin, large sales may be perceived as a way to sell out products with quality issues and personal instore recommendations can be seen as a way for assistants to earn commissions. Chinese consumers will not buy a product that they do not know in these circumstances. Therefore, when launching a new product, having in-store sales or sales personnel recommending the product too much can be a bad beginning for the product and/or brand.

Regarding post-purchase behaviour, consumers in China tend not to be very loyal towards cosmetic brands. However, several respondents in Shanghai are becoming more loyal towards brands they found have a unique specificity or effect. Therefore, a good strategy to increase customers' loyalty could be to emphasise a unique feature of the brand or product that is hard to find on others.

Another post-purchase issue to address is the lack of active complaining behaviour. Although more active in Switzerland than in China, passive complaining behaviour can be a problem for cosmetic manufacturers, as they do not have the opportunity to address possible issues directly, which could mean losing these customers. Therefore, marketers should encourage feedback from users, and provide them with special channels for that purpose. Yang, Fam, and Richard (2014, p. 45) found that responses tended to follow a "U-shaped relationship between satisfaction and online WOM (word of mouth)" with the most satisfied and dissatisfied actively complaining while the remainder remained quiet.

Brand managers and marketers should be aware that there is very significant variation across China even with relatively narrowly defined market segments. Our study shows that female cosmetic consumers aged 20 to 39 behave quite differently across two cities separated by climate, economic sophistication and international access: Rather than considering the whole of China to be homogeneous, marketers could develop differentiated strategies by considering the varying purchasing behaviours of consumers within the country.

\section{References}

Arkes, H. R., Joyner, C. A., Pezzo, M. V., Nash, J. G., Siegel-Jacobs, K., \& Stone, E., (1994), "The psychology of windfall gains", Organizational Behaviour and Human Decision Processes, vol. 59, no. 3, pp. 331-347.

Belk, R., Fischer, E., \& Kozinets, R., (2013), Qualitative consumer \& marketing research, Sage, Publication London.

Braun, V., \& Clarke, V., (2006), "Using thematic analysis in psychology", Qualitative Research in Psychology, vol. 3, no. 2, pp. 77-101.

Choi, J., Kim, K., \& Kim, M., (2007), "Cosmetics buying patterns and satisfaction among female university students in China, Japan and Korea", Journal of the Korean Society of Clothing and Textiles, vol. 31, no. 12, pp. 1772-1783.

Cobb-Walgren, C., Ruble, C., \& Donthu, N., (1995), "Brand equity, brand preference, and purchase intent", Journal of Advertising, vol. 24, no. 3, pp. 25-40. 
Connolly, A., \& Davison, L., (1996), "How does design affect decision at point of sale?", Journal of Brand Management, vol. 4, no. 2, pp. 100-107.

Cosmetics Business, (2012), "Switzerland - Ahead of the game", Retrieved from https://www.cosmeticsbusiness.com/technical/article_page/Switzerland_Ahead_of_th e_game $/ 49117$

Cosmetics Europe, (2016), "Socio-economic contribution of the European cosmetics industry", Retrieved from https://www.cosmeticseurope.eu/files/2214/6582/1941/Cosm etics_Europe_Socioeconomic_Contribution_of_the_European_Cosmetics_Industry_20 16.pdf

Cosmoprof-Asia, (2013), "China's cosmetics market: One size does not fit all”, Retrieved from http://www.cosmoprof-asia.com/blog/index.php/chinas-cosmetics-market-one-siz e-does-not-fit-all/

Davies, H., \& Raskovic, M., (2018), Understanding a changing China, Routledge, New York.

Engel, J., Blackwell, R., \& Kollat, D., (1978), Consumer behaviour, Dryden Press, Illinois.

Euromonitor International, (2017), "Beauty and personal care in Switzerland", Retrieved from http://www.euromonitor.com/beauty-and-personal-care-in-switzerland/report

Fung Business Intelligence Centre, (2013), "China's cosmetics market, 2012”, Retrieved from http://www.iberchina.org/files/china_cosmetics_market.pdf

Fung Business Intelligence Centre, (2015), "China's cosmetics market”, Retrieved from http://www.iberchina.org/files/cosmeticos_china_fung.pdf

Hawkins, D., \& Mothersbaugh, D., (2010), Consumer behaviour: Building marketing strategy, McGraw-Hill Irwin, Boston.

HKTDC Research, (2015), "China's cosmetics market”, Retrieved from http://china-traderesearch.hktdc.com/business-news/article/China-Consumer-Market/China-s-CosmeticsMarket/ccm/en/1/1X000000/1X002L09.htm

Hou, M., Wu, X., \& Hu, Z., (2013), "Personnel service, consumption emotion, and patronage intention in department stores", International Business Research, vol. 6, no. 3, pp. 621.

Huang, R., \& Sarigollu, E., (2012), "How brand awareness relates to market outcome, brand equity, and the marketing mix", Journal of Business Research, vol. 65, no. 1, pp. 92-99.

Janakiraman N., Meyer, R. J., \& Morales, A. C., (2006), "Spill-over effects: How consumers respond to unexpected changes in price and quality", Journal of Consumer Research, vol. 33, no. 3, pp.361-69.

Javidan, M., \& House, R., (2002), "Leadership and cultures around the world: Findings from GLOBE", Journal of World Business, vol. 37, no. 3, pp.1-2.

Jones, M., (1999), "Entertaining shopping experiences: An exploratory investigation", Journal of Retailing and Consumer Services, vol. 6, no. 3, pp.129-139.

Katona, G., \& Mueller, E., (1955), Consumer behaviour: The dynamics of consumer research, New York University Press, New York.

Khalid, K., Hilman, H., \& Kumar, D., (2012), "Get along with quantitative research process", International Journal of Research in Management, vol. 2, no. 2, pp. 15-29.

La Bua, R., (2011), "Estée Lauder Switzerland: Up close and personal - Swiss Style Magazine", Retrieved from http://www.swissstyle.com/up-close-and-personal/

Łatuszyńska, M., Furaiji, F., \& Wawrzyniak, A., (2012), "An empirical study of the factors influencing consumer behaviour in the electric appliances market", Contemporary Economics, vol. 6, no. 3, pp. 76.

Lautiainen, T., (2015), "Factors affecting consumers' buying decision in the selection of a coffee brand", Bachelor's, Saimaa University of Applied Sciences.

Lee, S. H., (2005), "An application of a five-stage consumer behaviour decision making model: An exploratory study of Chinese purchasing of imported health food", Master of Business Administration, Simon Fraser University.

Marquis, C., \& Yang, Z., (2014), "Learning the hard way: Why foreign companies that fail in China haven't really failed", Retrieved from https://ecommons.cornell.edu/bitstream /handle/1813/40209/Failures_CPR.pdf?sequence $=4$ 
Mostert, P., (2002), "Buying behaviour of South African internet users", Doctoral Commercii (Marketing Management), University of Pretoria.

Nguyen, A. N., (2012), Consumer behaviour toward foreign versus domestic branded cosmetics: A case study in Shenzhen, China, University of Phoenix, United States.

Paddison, A., \& Olsen, K., (2008), "Painkiller purchasing in the UK", International Journal of Pharmaceutical and Healthcare Marketing, vol. 2, no. 4, pp. 284-306.

Ponder, N., (2013), Consumer attitudes and buying behaviour for home furniture, Mississippi State University, Mississippi.

Pouromid, B., \& Iranzadeh, S., (2012), "The evaluation of the factors effects on the brand equity of Pars Khazar household appliances based on the vision of female consumer", Middle-East Journal of Scientific Research, vol. 12, no. 8, pp. 1050-1055.

Price, L. L., \& Feick, L. F., (1984), "The role of interpersonal sources in external search: An informational perspective", Advances in Consumer Research, vol. 11, pp. 250-255.

Punj, G., \& Srinivasan, N., (1992), "Share influence of problem recognition on search and other decision process variables: A framework for analysis", Advances in Consumer Research, vol. 19, pp. 491-497.

Reportlinker, (2015), "China cosmetics market report, 2014-2017”, Retrieved from https://www.reportlinker.com/p01662479/China-Cosmetics-Industry-Report.html

Roberts, A., (2014), "L'Oreal's Garnier joins Revlon in pulling out of China", Retrieved from https://www.bloomberg.com/news/articles/2014-01-08/1-oreal-s-garnier-joins-revlonin-pulling-out-of-china

Robertson, T. S., (1971), Innovative behaviour and communication, Rinehart and Winston.

Sandhusen, R., (2000), Marketing, Barron's, New York.

Sasmita, J., \& Mohd Suki, N., (2015), "Young consumers' insights on brand equity", International Journal of Retail \& Distribution Management, vol. 43, no. 2, pp. 276292.

Schiffman, L. G., \& Kanuk, L. L., (2007), Consumer behaviour, Pearson Prentice Hall, New Jersey.

Seo, H., (2002), "A qualitative investigation of Polish consumers' retail experiences during the transitional period: 1989-2001", Doctoral Dissertations, The University of Tennessee.

SSRCC, (2016), Internal research, Unpublished.

Tan, C., (2010), "Understanding consumer purchase behaviour in the Japanese personal grooming sector", Journal of Yasar University, vol. 17, no. 5, pp. 2821-2831.

Tendai, M., \& Crispen, C., (2009), "In-store shopping environment and impulsive buying", African Journal of Marketing Management, vol. 1, no. 4, pp.102-108.

U.S. Commercial Service Hong Kong, (2015), "Cosmetics \& toiletries market overviews 2015", Retrieved from http://trade.gov/industry/materials/ITA.FSC.Cosmoprof.2015_f inal2.pdf

United Nations, (2015), "World investment report 2015", Retrieved from http://unctad.org/en/PublicationsLibrary/wir2015_en.pdf

Whyte, M. K., (2009), "Paradoxes of China's economic boom", The Annual Review of Sociology, vol. 35, no. 1, pp. 371-392.

World Bank, (2016), "Gross domestic product 2014", Retrieved fromhttp://databank.worldbank.org/data/download/GDP.pdf

Yang, L., Fam, K., \& Richard, J., (2014), "Word-of-mouse" in China: In-depth interviews", Asian Journal of Business Research, vol. 4, no. 2, pp. 40-51.

Yip, C. Y. T., Chan, K., \& Poon, E., (2012), "Attributes of young consumers' favourite retail shops: A qualitative study", Journal of Consumer Marketing, vol. 29, no. 7, pp. 545552.

Zaichkowsky, J. L., (2015), "Review and reply to: Why you must use my C-OAR-SE method", Australasian Marketing Journal, vol. 23, no. 3, pp. 261.

Zulauf, C., (2002), "Einblick in die Welt der Cosmeceuticals", Retrieved from http://www.cosmeceuticals.ch/de/produkte/janssen/download/Einblick_Cosmeceuticals .pdf 